\title{
ANALISIS YURIDIS TERHADAP KEDUDUKAN HUKUM PERJANJIAN PENGIKATAN JUAL BELI HAK ATAS TANAH YANG BERSERTIFIKAT YANG DIBUAT DI BAWAH TANGAN (STUDI PUTUSAN NO. 130/PDT.G/2012/PN. MLG)
}

Satria Ginting, Program Studi Magister Kenotariatan

Fakultas Hukum Universitas Sumatera Utara Jalan Dr. T. Mansur Nomor 9, Kampus Padang Bulan, Medan

Telp.(061)8211633, Email: muarifarif11@gmail.com tryaginting@gmail.com

\section{JURIDICAL ANALYSIS ON LEGAL STANDING IN TRANSACTION CONTRACT OF UNDERHANDED CERTIFIED LAND \\ (A STUDY ON'THE RULING NO. 130/PDT.G/2012/PN.MLG)}

Satria Ginting, 177011031

J1. Bunga Rinte, Gg. Mawar 2, Simpang Selayang, Medan Tuntungan, Medan tryaginting@gmail.com

\section{ABSTRACT}

The use of underhanded deed in making PPJB (transaction contract) offen causes fraud or bad faith either by buvers or sellers as it is specified in the Verdict No. $130 / P$ dt. G/2012/PN.Mig as the research subject on bad faith of the seller in using underhanded contract. The objective was to analyze and to implement transaction of underhanded certified land according to $P P$ No. $24 / 1997$ on Land Registration. Legal standing of underhanded land certificate in land transaction and legal protection for buyers in the transaction of underhanded certified land is specified in the Verdict No. $130 / P$ dt. G/2012/PN.MIg.

The research used juridical normative method; its specification was descriptive analytic approach which described analyzed and presented the fact systematically to make it easier to understand. It was concluded and analyzed qualitatively. The data were organized systematically to get the clarity of a underhanded land transaction contract concerning law and legal standing.

The result of the research shows that the process of land title transfer through transaction according to PP No. 24/1997which includes, first, preparation of making land tramsaction contract, secondly, the implementation of making the certificate by PPAT; thirdly, registering the title transfer in which $P P A T$ is required to submit the certificate and other documents for registering the land title transfer to the Land Office no later than 7 work days; fourthly, handing in certificate. Both the seller and the buyer, according to the Verdict No. $130 / P d t . G / 2012 / P N . M 19$, are right since underhanded contract is not prohibited in a transaction contract which is confirmed by the Supreme Court's Ruling No. 126. K/Sip/1976 on April 4, 1978 which states that "Land transaction will be valid even though it is not made before a PPAT; it is only evidence." Legal protection for a buyer who buys something from a default seller is that underhanded contract is validated when the seller hands in SHGB No. 984, the land area is $150 \mathrm{~m}^{2}$ in the name of PT. Dewata Abdi Nusa with GS No. 00243/2007 on October 4, 2007 the seller is required to submit AJB (Purchase Agreement) of SHGB land No. 984 the land area of $150 \mathrm{~m}^{2}$ in the name of $P T$. Dewata Abdi Nusa with GS No. $00243 / 2007$ on October 4, 2007 .

Keywords: Underhanded Certificate, Contract, Transfer

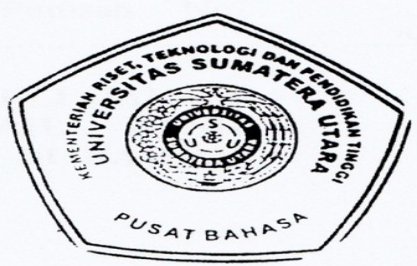

Intisari 
Penggunaan akta bawah tangan dalam melaksanakan perjanjian pengikatan jual beli (PPJB) sering kali menjadi dasar atau peluang dalam kecurangan atau melaksanakan itikad tidak baik oleh salah satu pihak, baik pihak pembeli maupun pihak penjual. putusan No. 130/Pdt.G/2012/PN.Mlg menjadi bahasan penelitian terkait adanya itikad tidak baik penjual pada jual beli yang dilakukan secara bawah tangan. Mengetahui sekaligus menganalisis pelaksanaan jual beli hak atas tanah yang bersertifikat menurut Peraturan Pemerintah No. 24 Tahun 1997 Tentang Pendaftaran Tanah, kedudukan hukum akta di bawah tangan dalam jual beli hak atas tanah dikaitkan dengan Putusan No. 130/Pdt.G/2012/PN.Mlg, perlindungan hukum bagi pembeli dalam jual beli hak atas tanah yang bersertifikat yang dilakukan di bawah tangan dikaitkan dengan Putusan No. 130/Pdt.G/2012/PN.Mlg Jenis penelitian ini adalah yuridis normatif, Spesifikasi penelitian ini bersifat deskriptif analisis dan sifat penelitian yang digunakan yaitu penelitian deskriptif analitis. Penelitian ini melakukan analisis hanya sampai pada taraf deskripsi, yaitu menganalisis dan menyajikan fakta secara sistimatis sehingga dapat lebih mudah untuk dipahami dan disimpulkan serta dianalisis secara kualitatif, yaitu data yang diperoleh kemudian disusun secara sistematis untuk selanjutnya dianalisis untuk mencapai kejelasan mengenai perjanjian secara bawah tangan menyangkut hukum dan kedudukanya. Hasil penelitian yaitu Proses peralihan hak atas tanah melalui jual beli menurut Peraturan Pemerintah Nomor 24 Tahun 1997 meliputi: pertama, persiapan pembuatan akta jual beli hak atas tanah. Kedua, pelaksanaan pembuatan akta PPAT. Ketiga, pendaftaran peralihan hak, PPAT wajib menyampaikan akta PPAT dan dokumendokumen lain yang diperlukan untuk keperluan pendaftaran peralihan hak atas tanah yang bersangkutan kepada kantor pertanahan kabupaten/kota selambat-lambatnya tujuh hari kerja. Keempat, penyerahan sertifikat. Kedudukan para pihak dalam jual beli pada Putusan No. 130.Pdt.G/2012/PN. Mlg tidak ada yang salah hal ini karenakan perjanjian bawah tangan tidak menjadi larangan dalam jual beli hal ini dipertegas oleh Yurisprudensi Mahkamah Agung Nomor 126.K/Sip/ 1976 tanggal 4 April 1978 yang memutuskan bahwa :"Untuk sahnya jual beli tanah, tidak mutlak harus dengan akta yang dibuat oleh dan dihadapan Pejabat Pembuat Akta Tanah. Akta Pejabat ini hanyalah suatu alat bukti". Perlindungan hukum berdasarkan putusan terhadap pembeli yang mana penjual wanprestasi yaitu disahkanya perjanjian bawah tangan, mewajibkan penjual menyerahkan SHGB No. 984 Luas $150 \mathrm{~m}^{2}$ atas nama pt. Dewata Abdi Nusa dengan GS No. 00243/2007 tanggal 04 Oktober 2007, mewajibkan penjual mengajukan akta jual beli (AJB) tanah SHGB No. 984 Luas $150 \mathrm{~m}^{2}$ atas nama pt. Dewata Abdi Nusa dengan GS No. 00243/2007 tanggal 04 Oktober 2007.

Kata Kunci : Akta Bawah Tangan, Perjanjian, Peralihan

\section{A. Latar Belakang}

Perjanjian jual beli hak

atas tanah dan bangunan

berbeda dengan perjanjian

jual beli pada umumnya yang

diatur dalam KUHPerdata.

Perjanjian jual beli hak atas

tanah dan bangunan, memiliki pengaturan secara

khusus dalam

pelaksanaannya. Perjanjian

jual beli hak atas tanah dan

bangunan secara umum harus

memenuhi ketentuan yang

berlaku dalam KUHPerdata.

Perjanjian jual beli dalam 
pengertian KUHPerdata adalah merupakan perjanjian bernama yang diatur dalam Pasal 1457 sampai dengan 1540 KUHPerdata, yaitu perjanjian yang dikenal dengan nama tertentu dan mempunyai pengaturannya secara khusus dalam UndangUndang. ${ }^{1}$

Praktek jual beli tanah dalam masyarakat menjadi sebuah bukti pelaksanaaan sistem hukum, sistem terang tunai menunjukkan bahwa pembeli memberikan langsung sejumlah uang untuk harga tanah yang telah disepakati dan disaat itu juga tanah beralih kepada pembeli. Tanah bersertifikat lebih dimudahkan pada transaksi jual beli karena pada akhirnya secara bersama sama antara penjual dan pembeli tinggal membalikkan nama pemilik awal terhadap pemilik baru.

PPJB berakhir apabila para pihak telah melakukan perjanjian jual beli

1 Juswito Satrio, Hukum

Perikatan, Perikatan yang Lahir dari Perjanjian, Citra Aditya Bakti, Bandung:2002, h. 14
Berdasarkan uraian tersebut, maka dapat diketahui bahwa perjanjian pengikatan jual beli secara umum berfungsi sebagai perjanjian awal atau perjanjian pendahuluan yang memberikan penegasan bagi para pihak untuk melakukan perjanjian pokok (perjanjian jual beli), serta menyelesaikan suatu hubungan hukum antara para pihak, apabila janji-janji yang telah disepakati dalam perjanjian pengikatan jual beli tersebut telah dilaksanakan seutuhnya.

$\begin{array}{rr} & \text { Penggunaan akta } \\ \text { bawah } & \text { tangan dalam }\end{array}$ melaksanakan perjanjian pengikatan jual beli (PPJB) sering kali menjadi dasar atau peluang dalam kecurangan atau melaksanakan itikad tidak baik oleh salah satu pihak, baik pihak pembeli maupun pihak penjual. $^{2}$ Perjanjian secara bawah tangan sering menjadi titik awal terjadinya niat ataupun 2 Salim HS, 2003, Hukum Kontrak, Penerbit Sinar Grafika, Jakarta.h. 23 
timbulnya itikad tidak baik oleh salah satu pihak sebagaimana yang tercermin pada putusan yang digunakan penulis sebagai acuan dalam penyelesaian tesis ini yaitu putusan No. 130/Pdt.G/2012/ PN.Mlg. pemilihan putusan yang digunakan dalam tesis ini berdasarkan penelusuran penulis terhadap kasus yang berhubungan di respostori publikasi pengadilan. Kecocokan pokok permasalah putusan yang bersumber dari pengadilan negeri malang yang pada intinya mempermasalahkan jual yang dilakukan berdasarkan akta dibawah tangan dengan kajian judul menjadi dasar kuat dalam pemilihan putusan No. 130/Pdt.G/2012/PN.Mlg menjadi bagian pokok dalam tesis ini.

Permasalah dalam putusan berawal dari saudari LS membeli rumah kapling dari DPRW salah seorang pemilik dan pengembang Perumahan Graha Dewata PT Dewata Abdi Nusa, rumah yang dibeli tersebut beralamat di Blok JJ 2 No 1 c yang terletak di Ds Landungsari kec. Dau, Kab. Malang, dengan SHGB No 984 luas $150 \mathrm{M}^{2}$ an dengan GS No 00243/2007 ttg 4 Oktober 2007. Pembelian yang dilakukan oleh LS dituangkan dalam surat perjanjian jual beli SPJB NO. 001/ dan. SPJ / I / 2011 ttg. 11 januari 2011. Sistem pelunasan yang diterapkan tunai bertahap, kebertahapan dilakukan dengan dua pembayaran yang pada pembayaran kedua dilakukan dengan penyerahan SHGB bangunan. Selanjutnya dalam perjanjian tersebut menerangkan bahwa apabila pengugat telah melunasi bangunan rumah yang telah dibeli LS, maka DPRW akan mengurus akta jual belinya terhadap notaris dan menyerahkan terhadap LS. Akan tetapi setelah rumah tersebut selesai dibangun SHGB yang telah diperjanjiakan tidak kunjung 


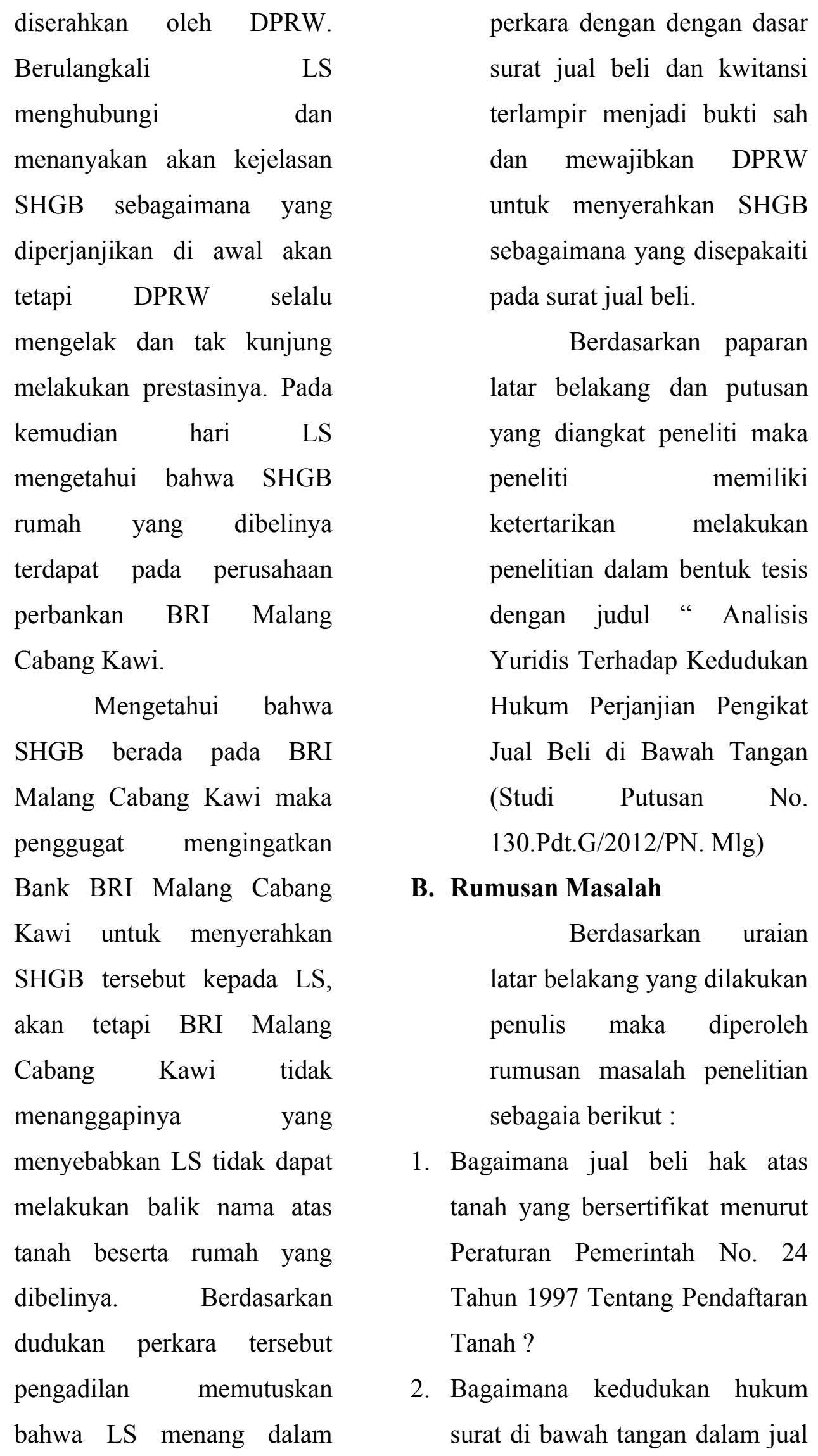


beli hak atas tanah dikaitkan dengan Putusan No. 130/Pdt.G/2012/PN.Mlg?

3. Bagaimana perlindungan hukum bagi pembeli dalam jual beli hak atas tanah yang bersertifikat yang dilakukan di bawah tangan dikaitkan dengan Putusan No. 130/Pdt.G/2012/PN.Mlg ?

\section{Metode Penelitian}

Jenis penelitian ini adalah yuridis normatif, yaitu dengan mengkaji peraturan perundang-undangan, teoriteori hukum dan yurisprudensi yang berhubungan dengan permasalahan yang dibahas. ${ }^{3}$. Pelaksanaan penelitian normatif dalam penelitian ini dilakukan dengan meneliti kedudukan PPJB yang dilakukan secara bawah tangan yang mengalami sengketa hingga ke pengadilan.

\section{PEMBAHASAN}

Pelaksanaan Jual Beli Hak Atas Tanah Yang Bersertifikat Menurut Peraturan Pemerintah No. 24 Tahun 1997 Tentang Pendaftaran Tanah

$\begin{array}{lll}{ }^{3} \text { Rony } & \text { Hanitijo } & \text { Soemitro, } \\ \text { Metode Penelitian Hukum dan } & \text { Jurimetri, } \\ \text { Ghalia Indonesia, Jakarta, 1988, h.9 }\end{array}$

\section{Kajian Pelaksanaan Jual Beli} Tanah

\section{Jual Beli Secara Umum}

Jual beli tanah diatur dalam Undang-undang Pokok Agraria, yaitu Undangundang No. 5 Tahun 1960, yang selanjutnya diatur di dalam Peraturan Pemerintah No. 24 Tahun 1997 tentang Pendaftaran Tanah (dahulu diatur dalam PP Nomor 10 tahun 1961 tentang pendaftaran tanah), yang merupakan peraturan pelaksanaan daripada Undang-undang No.5 Tahun $1960^{4}$.

Pasal 1458 Kitab

Undang-Undang Hukum Perdata, disebutkan bahwa "Jual beli dianggap telah terjadi antara kedua belah pihak, seketika setelah orangorang ini mencapai sepakat tentang kebendaan tersebut dan harganya, meskipun kebendaan itu belum disahkan maupun harganya

${ }^{4}$ Djaja S. Meliala, Perkembangan Hukum Perdata Tentang Benda dan Hukum Perikatan, Nuansa Aulia, Bandung, 2008, h.99 
belum dibayar." Jual beli

dalam Hukum Perdata

tersebut bersifat obligator

artinya bahwa perjanjian jual

beli baru meletakkan hak dan

kewajiban timbal balik antara

kedua belah pihak (penjual

dan pembeli) yaitu

meletakkan pada penjual

kewajiban

untuk

menyerahkan hak milik atas barang yang dijualnya, sekaligus memberikan kepadanya hak untuk menuntut pembayaran harga yang telah disetujui dan di lain pihak meletakkan kewajiban kepada pembeli untuk membayar harga barang sebagai imbalan haknya, untuk menuntut penyerahan hak milik atas barang yang dibelinya ${ }^{5}$.

Jual beli tanah menurut hukum agraria nasional (yang mengacu pada hukum adat) tidak sama dengan jual beli menurut hukum perdata, dimana peralihan haknya masih perlu

\footnotetext{
${ }^{5}$ Salim H.S.,Hukum Kontrak Teori dan Teknik Penyusunan Kontrak, Sinar Grafika, Jakarta, 2003, h. 49.
}

adanya perbuatan hukum yang berupa penyerahan barang (levering). Jual beli tanah tersebut sudah terjadi dan hak atas tanah sudah beralih pada pembeli pada saat harga dibayar dan hak atas tanah diserahkan dan dibuatkan akta jual beli oleh PPAT.

\section{Berdasarkan}

KUHPerdata pasal 1457, Jual beli yang dianut di dalam Hukum Perdata hanya bersifat obligatoir, artinya bahwa perjanjian jual beli baru meletakkan hak dan kewajiban timbal balik antara kedua belah pihak, atau dengan perkataan lain jual beli yang dianut Hukum Perdata belum memindahkan hak milik adapun hak milik baru berpindah dengan dilakukan penyerahan atau levering. Uraian tersebut diatas, jual beli tanah menurut Hukum Perdata terdiri dari/atas 2 (dua) bagian yaitu perjanjian jual belinya dan penyerahan haknya, keduanya terpisah 
satu dengan lainnya.

Sehingga, walaupun hal yang pertama sudah selesai biasanya dengan akta notaris, tapi kalau hal yang kedua belum dilakukan, maka status tanah tersebut masih tetap hak milik penjual.

\section{Syarat-syarat Jual Beli Tanah}

\author{
Syarat-syarat dalam \\ perbuatan hukum terhadap \\ pengalihan hak atas tanah \\ terbagi atas 2 (dua) macam, \\ yaitu: ${ }^{6}$
}

\section{a. Syarat Materiil}

Syarat materiil sangat menentukan akan sahnya jual beli tanah tersebut, antara lain sebagai berikut ${ }^{7}$ :

1) Penjual adalah orang yang berhak atas tanah yang akan dijualnya.

2) Pembeli adalah orang yang berhak untuk mempunyai hak atas tanah yang dibelinya.

${ }^{6}$ Erza Putri, Peran PPAT Dalam Peralihan Hak Atas Tanah, http://erzaputri. blogspot.com.

7 Kartini Muljadi dan Gunawan Widjaja, Perikatan Yang Lahir dari Perjanjian, PT Grafindo Persada, Jakarta, 2004, h.91
3) Tanah yang bersangkutan boleh diperjual belikan atau tidak dalam sengketa.

b. Syarat Formil

Setelah semua persyaratan materiil tersebut terpenuhi, maka dilakukan jual beli dihadapan PPAT. Dalam pelaksanaan jual beli yang dibuat oleh PPAT hal-hal yang harus diperhatikan adalah:

\section{Tata Cara Jual Beli Tanah}

Apabila pemegang hak hanya satu, maka ia berhak untuk menjual sendiri tanah itu, tapi jika pemegang hak atas tanah tersebut terdiri dari dua orang atau lebih, maka yang berhak menjual tanah itu adalah semua pemegang hak itu secara bersama-sama tidak boleh hanya seorang saja yang bertindak sebagai penjual beli tanah yang dilakukan oleh orang yang tidak berhak adalah batal demi hukum.

Kedua adalah, apakah penjual berwenang untuk menjual, mungkin terjadi bahwa seseorang berhak atas suatu hak atas tanah akan 
tetapi orang itu tidak berwenang menjualnya kalau tidak dipenuhi syarat tertentu, Ketiga yang perlu diperhatikan adalah, apakah penjual boleh menjual tanah yang akan dijadikan obyek jual beli. Keempat adalah, apakah penjual atau pembeli bertindak sendiri atau sebagai kuasa Penjual/Pembeli mungkin bertindak sendiri atau selaku kuasa. Baik penjual/pembeli bertindak sendiri maupun melalui kuasa, identitasnya harus jelas.

Tata cara dalam pelaksanaannya menurut UUPA dengan peraturan pelaksaannya, secara sederhana dapat diuraikan sebagai berikut ${ }^{8}$ :

a) Calon pembeli dan penjual sepakat untuk melakukan jual beli menentukan sendiri segala sesuatunya, tentang tanah dan harganya.

${ }^{8}$ Boedi Harsono, Hukum Agraria Indonesia, Sejarah Pembentukan UndangUndang Pokok Agraria, Isi dan Pelaksanaanya, Hukum Tanah Nasional Jilid 1, Djambatan, 2003, Jakarta, h. 333. b) Calon pembeli dan penjual datang sendiri atau mewajibkan kepada orang lain dengan surat kuasa, menghadap kepada Pejabat Pembuat Akta Tanah (PPAT) (Kepala Kecamatan, Notaris atau lainnya yang diangkat oleh pemerintah).

c) Dalam hal tanah yang akan dijual itu belum dibukukan (belum bersertifikat), maka diharuskan kehadiran Kepala Desa atau seorang anggota Pemerintah Desa yangdisamping akan bertindak sebagai saksi, juga menjamin bahwa tanah yang akan dijual itu memang betul adalah milik penjual dan ia berwenang untuk menjualnya.

d) Dalam hal tanah yang akan dijual itu sudah dibukukan (sudah ada sertifikat) di hadiri dua orang saksi, tidak harus Kepala Desa dan anggota pemerintah desa.

e) Kalau tanah yang dijual telah dibukukan, penjual harus menyerahkan sertifikat, tetapi kalau belum di bukukan 
sebagai gantinya harus dibuat surat keterangan dari Kepala Kantor Pertahanan yang menyatakan bahwa tanah itu belum dibukukan

f) Setelah PPAT merasa cukup persyaratan, tidak ada halangan (umpamanya ada persengketaan) dan tidak ragu-ragu lagi, maka PPAT membuat Akta Jual Bali Tanah tersebut.

g) Selanjutnya dengan telah adanya akta tersebut, maka PPAT menguruskan pendaftaran sampai mendapat sertipikat. ${ }^{9}$

\section{Jual Beli tanah bersertifikat}

Akta jual beli hak atas tanah yang dilakukan dihadapan Pejabat Pembuat Akta Tanah (PPAT) merupakan salah satu persyaratan untuk melakukan pendaftaran peralihan hak atas tanah di Kantor Pertanahan, hal ini akan berimplikasi pada kepastian hukum tentang status tanah tersebut. Dengan demikian

9 Kartini Muljadi dan Gunawan Widjaja, Perikatan Pada Umumnya, PT Grafindo Persada, Jakarta, 2004,Cet-2,h. 19 berarti, agar peralihan hak atas tanah, dan khususnya hak milik atas tanah tersebut dapat terselenggara secara benar, maka seorang PPAT yang akan membuat peralihan hak atas tanah harus memastikan kebenaran mengenai hak atas tanah (hak milik) tersebut, dan mengenai kecakapan dan kewenangan bertindak dari mereka yang akan mengalihkan dan menerima pengalihan hak atas tanah tersebut.

Balik nama Sertifikat hak atas tanah sebagai akibat telah dilakukannya jual beli tanah menurut hukum adat dalam pelaksanaannya biasanya hanya dibuat surat yang isinya menyatakan bahwa penjual telah menyerahkan tanahnya dan menerima uang pembayaran $^{10}$, tetapi tidak dibuktikan dengan adanya akta jual beli tanah yang dibuat dihadapan Pejabat

10 Agusman, Rodeka Siregar. Problematika Pendaftaran Tanah Adat Menjadi Hak Milik Tanpa Persetujuan Seluruh Ahli Waris pada Kantor Pertanahan Kabupaten Samosir. Magister Kenotariatan USU, Medan, 2017. h.12 
Pembuat Akta Tanah (PPAT) yang telah ditetapkan oleh peraturan perundangundangan yang berlaku ${ }^{11}$.

Jual Beli Hak Atas Tanah yang Bersertifikat Menurut Peraturan Pemerintah Nomor 24 Tahun 1997 tentang Pendaftaran Tanah

Berdasarkan Pasal 37 ayat (1) Peraturan Pemerintah Nomor 24 Tahun 1997 tentang Pendaftaran Tanah, setiap pemindahan hak atas tanah kecuali yang melalui lelang hanya bisa didaftarkan apabila perbuatan hukum pemindahan hak atas tanah tersebut didasarkan pada akta PPAT. Notaris dan PPAT sangat berperan dalam persentuhan antara perundang-undangan dan dunia hukum, sosial dan ekonomi praktikal. Notaris adalah pejabat umum (openbaar ambtenaar) yang bertanggung jawab untuk membuat surat keterangan tertulis yang dimaksudkan sebagai alat bukti dari

11 Riduan Syahrani, Seluk Beluk Dan Asas-Asas Hukum Perdata, Alumni, Bandung, 2004, h. 209. perbuatan-perbuatan hukum (Herlien, 2006:256).

Menghadapkan inti pembahasan tesis ini dengan peraturan pemerintah Nomor 24 tahun 1997 dimana pada pokonya menjelaskan peralihan hak di yang telah diperbuat Notaris/PPAT untuk selanjutnya di daftarkan kepada badan pertanahan dalam rangka mengubah identitas kepemilikan sebelumnya menjadi identitas pemilik baru. Badan pertanahan dalam memproses perubahan sebagaimana diatas hanya menerima dan mendasarkan pada akta jual beli yang telah dibuat notaris/PPAT. Terkait jual beli yang dilakukan dengan PPJB baik secara lunas maupun bertahap kebutuhan sebagaiman pada peraturan pemerintah Nomor 24 tahun 1997 tidak dapat dilaksanakan. Keterbatasan PPJB tersebut kembali pada subtansi hukumnya sendiri, PPJB diterbitkan hanya sebagai penanda bahwa 
adanya keterikatan atau kesepakatan untuk melakukan jual beli, akan tetapi subbstansi pemindahan hak belum tertera didalamnya. Ketidak terdapatan substansi tersebut menjadikan PPJB tidak dapat digunakan sebagai dasar pendaftaran peralihan hak kepada BPN.

Kedudukan Hukum Akta Di Bawah Tangan Dalam Jual Beli Hak Atas Tanah Dikaitkan Dengan Putusan No. 130/Pdt.G/2012/Pn.MIg

Mengenai akta di bawah tangan, ada beberapa hal yang perlu diketahui, yaitu dalam Pasal 1877 KUHPerdata disebutkan bahwa, jika seseorang memungkiri tulisan atau tanda tangannya, maka hakim harus memerintahkan supaya kebenaran daripada tulisan atau tanda tangan tersebut diperiksa di muka pengadilan. Perbedaan pokok antara akta otentik dengan akta di bawah tangan adalah cara pembuatan atau terjadinya akta tersebut ${ }^{12}$.

Pengertian dari akta di bawah tangan ini dapat diketahui dari beberapa perundang-undangan sebagai berikut :

1) Pasal 101 ayat $b$ UndangUndang No. 5 Tahun 1986 Tentang Peradilan Tata Usaha Negara, menyatakan bahwa akta di bawah tangan

2) Pasal 1874 Kitab UndangUndang Hukum Perdata, menyatakan bahwa yang dianggap sebagai tulisan di bawah tangan adalah akta yang ditandatangani di bawah tangan, surat, daftar, surat urusan rumah tangga dan tulisan-tulisan yang lain yang dibuat tanpa perantaraan seorang pejabat umum.

Terdapat setidaknya dua kekurangan atau kelemahan akta di bawah tangan yang demikian itu. Pertama, ketiadaan saksi yang membuat akta di bawah tangan tersebut akan Tentang Jual Beli Tanah Berikut PeraturanPeraturannya, Ghlmia Indonesia, Jakarta, 1987, h 50. 


\begin{abstract}
kesulitan
untuk

membuktikannya. Kedua, apabila salah satu pihak memungkiri atau menyangkali tandatangannya, maka kebenaran akta di bawah tangan tersebut harus dibuktikan kebenarannya di muka pengadilan ${ }^{13}$. Karena kekurangan atau kelemahan inilah menjadi salah satu pertimbangan mengapa masyarakat dari waktu ke waktu semakin banyak menggunakan akta otentik untuk berbagai transaksi yang dilakukannya.
\end{abstract}

Mengenai akta di bawah tangan yang memuat pengakuan utang secara sepihak untuk membayar sejumlah uang atau memberikan/ menyerahkan sesuatu barang yang dapat ditetapkan atas suatu harga tertentu, harus seluruhnya ditulis dengan tangannya sendiri oleh pihak yang

13 Melda Nehemia Sitinjak, Analisis Yuridis Terhadap Perjanjian Pengikatan Jual Beli (PPJB) Unit Apartemen Sebagai Agunan Dalam Perjanjian Kredit Investasi (Studi Di PT. Bank Nationalnobu TBK). Magister Kenotariatan USU. 2016. h. 4 menandatangani (orang yang berutang) atau paling sedikit selain tanda tangannya, harus ditulis sendiri oleh si penandatangan (orang yang berutang) suatu persetujuan yang memuat jumlah atau besarnya barang yang terutang. Jika diindahkan, maka apabila perikatan dipungkiri, akta di bawah tangan itu hanya dapat diterima sebagai suatu permulaan pembuktian dengan tulisan, demikian menurut Pasal 1878 KUH Perdata, yang bersamaan isinya dengan Pasal $1291 \mathrm{Rbg}$ dan Pasal 4 Stbl. 1867 No. 29. Apa yang dimaksud dengan permulaan bukti tertulis, dijelaskan dalam Pasal 1902 ayat (2) KUH Perdata, yang berbunyi: "yang dinamakan permulaan pembuktian dengan tulisan ialah segala akta tertulis yang berasal dari orang terhadap siapa tuntutan dimajukan, atau dari orang yang diwakili olehnya, dan yang memberikan persangkaan 
tentang benarnya peristiwaperistiwa yang dimajukan oleh seseorang." 14

\section{Proses Jual Beli Tanah di Bawah}

\section{Tangan}

Jual beli yang tidak dibuat dihadapan Pejabat Pembuat Akta Tanah (PPAT) tetap sah meskipun hanya berdasarkan kwitansi. Hal itu didasarkan pada Yurisprudensi Mahkamah Agung Nomor 126.K/Sip/ 1976 tanggal 4 April 1978 yang memutuskan bahwa :

"Untuk sahnya jual beli tanah, tidak mutlak harus dengan akta yang dibuat oleh dan dihadapan Pejabat Pembuat Akta Tanah. Akta Pejabat ini hanyalah suatu alat bukti". ${ }^{15}$

$$
\text { Peneliti dalam }
$$
mengkaji masalah tentang perlindungan hukum terhadap pembeli beritikad baik dalam jual beli dengan perjanjian bawah tangan, milih 2

\footnotetext{
${ }^{14}$ Harun Al Rasyid, Sekilas Tentang Jual Beli Tanah (Berikut Peraturanperaturannya), (Jakarta, Ghalia Indonesia, 1987), hlm. 66

${ }^{15}$ Peraturan Pemerintah Nomor 24 Tahun 1997 Tentang Pendaftaran Tanah
}

putusan sebagai bahan analisa untuk menunjukkan persoalan yang terjadi terkait masalah yang diteliti dengan kenyataan pada kehidupan masyarakat.

Perjanjian semacam itu disebut tulisan di bawah tangan. Tulisan di bawah tangan membutuhkan pengakuan kebenaran atas tulisan tersebut dari para pihak dan saksi-saksi lain. Namun jika tanda tangan dalam tulisan di bawah tangan itu sudah diakui oleh para pihak, maka tulisan tersebut berkekuatan mengikat dan sempurna sebagai alat bukti., akan tetapi pemerintah telah menafsirkan terhadap sengketa yang akan ditimbulkan sistem tersebut oleh sebab itu pada ketentuan mendasarya pelaku hukum maupun pemerintah telah memberikan pasal 37 ayat (1) PP No. 24/ 1997 yang berbunyi ${ }^{16}$;

16 Achmad Chulaemi, Hukum Agraria dan Perkembangan, Macam-macam Hak Atas Tanah dan Pemindahannya, FHUNDIP, Semarang, 1996), h. 15. 
"Peralihan hak atas tanah dan hak milik atas satuan rumah susun melalui jual beli, tukar-menukar, hibah, pemasukan data perusahaan dan perbuatan hukum pemindahan hak karena lelang hanya dapat didaftarkan jika dibuktikan dengan akta yang dibuat oleh PPAT yang berwenang menurut ketentuan peraturan perundang-undangan yang berlaku".

Hal ini diberlakukan demi menjaga kepastian dan perlindungan hukum bagi setiap pelaku perjanjian serta mewujudkan peralihan hak yang sesuai dengan hukum.

Terkait dengan pembuktian dengan isi perjanjian bawah tangan yang di sampaikan dalam dudukan perkara pada putusan No. 130.Pdt.G/2012/PN. Mlg tidak dapat dijelaskan secara terperici hal ini disebabkan ketidak hadiran bahkan ketidak tahuan posisi tergugat yang mengakibatkan pemberian putusan berdasarkan sepihak. Peralihan tanah berikut dengan rumahnya dalam putusan yang diangkat peneliti menunjukkan tentang apa yang telah dibicarakan pada bab sebelumnya yaitu oleh penggunaan akta bawah tangan akan memunculkan itikad tidak baik salah satu pihak yang dalam hal ini putusan No. 130.Pdt.G/2012/ PN. Mlg itikad tidak baik dilakukan oleh penjual dengan wanprestasi terhadap kewajibanya untuk menyerahkan tanah berikut dengan rumah diatasnya sesuai dengan kesepakatan ${ }^{17}$.

Faktor-faktor yang Menyebabkan Mayarakat Melakukan Jual Beli Tanah di Bawah Tangan dikaitkan dengan Putusan No. 130/Pdt.G/2012/PN.Mlg

Masalah jual beli memang belum bisa diatasi seluruhnya oleh aparat ataupun pemerintah, salah satunya ialah pendaftaran sertifikat tanah hingga akta jual beli yang dilakukan di Bawah tangan ${ }^{18}$. Keberadaan

17 AP Parlindungan, H. Serba Serbi Hukum Agraria, Alumni, Bandung, 1984, h. 198

18 Paulus, Analisis Yuridis Terhadap Munculnya Sertipikat Hak Milik Atas Tanah Perkebunan Kelapa Sawit Perorangan Atas Kekuatan Surat Keterangan Kepala Desa Yang Ganda (Studi Putusan PTUN Nomor : 08/G/2011/PTUN-MDN. Magister 
akta jual beli di bawah tangan

memang tidak dapat lagi

dipungkiri, ada bamyak hal

yang

menyebabkan

masyarakat

memilih

melakukan jual beli dengan

akta di bawah tangan, salah

satunya yaitu karena belum

optimalnya pelaksanaan

pendaftaran tanah karena

adanya

beberapa

permasalahan, yakni sebagai

berikut ${ }^{19}$ :

1. Kurang lengkapnya Standar Operasional Prosedur (SOP) dan Standar Produk (SP).

2. Sering munculnya berbagai kasus sertifikat ganda

3. Kurang tersedianya peta skala besar

4. Perturan pemerintah Nomor 24 Tahun 1997 mengamanatkan bahwa pelaksanaan pendaftaran tanah harus sederhana, aman dan terjangkau.

5. Kecilnya jumlah bidang tanah yang terdaftar.

Kenotariatan USU. Medan. 2015. h. 45

${ }^{19}$ Munir Fuady, Hukum Kontrak (dari Sudut Pandang Hukum Bisnis, Citra Aditya Bakti, Bandung, 1999, h 87.
6. Banyaknya peraturan pertanahan lain yang bersifat komponen (unit kerja)

7. Hingga saat ini belum ada kesatuan penafsiran mengenai definisi tanah adat dan tanah Negara.

$$
\text { Putusan }
$$
No. 130/Pdt.G/2012/PN.Mlg tidak menjelaskan alasan pembeli secara rinci melakukan pembelian rumah secara bawah tangan, pembeli dalam putusan diterangkan memberikan pembayaran tanpa menjelaskan alasan yang jelas mengapa tidak melakukan perjanjian pengikat jual beli kepada notaris. Pada dasarnya jual beli yang melibatkan antara perusahaan pengembang dibarengi dengan akad yang dibuktikan dengan menghadapnya antara pembeli dan pihak pemilik perusahaan terhadap notaris guna menuangkan perjanjian jual beli yang dikehendaki.

\section{Para Pihak yang Terlibat dalam} Praktik Jual Beli Tanah di Bawah 
Tangan dikaitkan dengan Putusan No. 130/Pdt.G/2012/PN.Mlg

Putusan

No.

130/Pdt.G/2012/PN.Mlg

menjelaskan kedudukan

dimana pihak pengembang

perusahaan

wanprestasi

dalam penyerahan tanah dan

rumah yang telah dibeli dan

dibayar lunas oleh pembeli.

Para pihak yang terlibat

dalam jual beli mempunyai

hak dan kewajiban,

kewajiban penjual adalah

menjamin bahwa objek yang

diperjual belikan adalah sah

miliknya berdasarkan

undang-undang yang berlaku

dan tidak terikat dalam status

sengketa, sedangkan

kewajiban pembeli adalah

menyerahkan sejumlah uang

kepada penjual seperti yang

diperjanjikan. Perjanjian jual beli diatur dalam Bab $\mathrm{V}$ pasal 1457-1540 Kitab UndangUndang Hukum Perdata.

Kewajiban para pihak dalam putusan yaitu pihak pembeli berkewajiban melunasi pembayaran tanah dan rumah yang telah diperjanjiakan dibeli dengan lunas sebesar Rp. 120.000.000 (Seratus Dua Puluh Juta Rupiah dengan pembayaran secara 2 tahap yaitu cicilan pertama saat terjadinya pembelian sebesar Rp. 35.902.031 (Tiga Puluh Lima Juta Sembilan Ratus Dua Ribu Tiga Puluh satu Rupiah) dan cicilan kedua yaitu sebsar Rp. 84.097.969 (Delapan Puluh Empat Juta Sembilan Puluh Tujuh Ribu Sembilan Ratus Enam Puluih Sembilan Rupiah. Sedangkan kewajiban penjual yaitu menyerahkan tanah dan bangunan yang diperjanjikan dengan bukti awal yaitu penyerahan SHGB No. 984 luas $150 \mathrm{~m}^{2}$ atas nama PT. Dewata Abadi Nusa dengan GS No. 00243/2007 tanggal 4 Oktober 2007 yang terletak di Dusun Ladungsari Kec. Dau, Kab. Malang. Kewajiban berikutnya dari penjual yaitu melanjutkan pembuatan akta jual beli dari tanah yang diperjual belikan 
Dikarenakan

terjadinya perjanjian jual beli

para pihak terikat untuk

melaksanakan prestasinya,

bila salah satu pihak

melakukan wanprestasi maka

pihak yang dirugikan dapat melakukan tuntutan kepada pihak yang melakukan wanpretasi $^{20}$. Prestasi atau yang dalam bahasa Inggris disebut juga dengan istilah "performance" dalam hukum kontrak dimaksudkan sebagai suatu pelaksanaan hal-hal yang tertulis dalam suatu kontrak oleh pihak yang telah mengikatkan diri untuk itu, pelaksanaan mana sesuai dengan "term" dan "condition" sebagaimana disebutkan dalam kontrak yang bersangkutan ${ }^{21}$.

Menurut pasal 1238 KUH Perdata yang menyatakan bahwa: "Si berutang adalah lalai, apabila ia dengan surat perintah atau dengan sebuah akta sejenis itu telah

${ }^{20}$ Tan Kamello, Hukum Jaminan (suatu kebutuhan yang didambakan). Alumni. Bandung. h.67

${ }^{21}$ Kamus besar Indonesia dinyatakan lalai, atau demi perikatan sendiri, ialah jika ini menetapkan bahwa si berutang harus dianggap lalai dengan lewatnya waktu yang ditentukan"22.

\section{Sebab dan Akibat Wanprestasi}

Wanprestasi terjadi disebabkan oleh sebab-sebab sebagai berikut:

a. Kesengajaan atau kelalaian debitur itu sendiri. Unsur kesengajaan ini, timbul dari pihak itu sendiri.

b. Adanya keadaan memaksa (overmacht). Biasanya, overmacht terjadi karena unsur ketidaksengajaan yang sifatnya tidak diduga. Contohnya seperti kecelakaan dan bencana alam.

"Syarat batal dianggap selalu dicantumkan dalam persetujuanpersetujuan yang bertimabal nalik, manakala salah satu pihak tidak memenuhi kewajibannya. Dalam hal demikian persetujuan tidak batal demi hukum, tetapi pembatalan harus dimintakan

22 Pasal 1238 KUHPerdata Tentang Hak dan Kewajiban dalam jual beli. 
kepada hakim. Permintaan ini juga harus dilakukan, meskipun syarat batal mengenai tidak dipenuhinya kewajiban dinyatakan di dalam perjanjian.

Sebagaimana yang disebutkan dalam pasal 1236 dan 1243 "dalam hal debitur lalai untuk memenuhi kewajiban perikatannya kreditur berhak untuk menuntut penggantian kerugian, yang berupa ongkos-ongkos, kerugian dan bunga”. Selanjutnya pasal 1237 mengatakan, bahwa "sejak debitur lalai, maka resiko atas objek perikatan menjadi tanggungan debitur"23. Yang ketiga adalah bahwa kalau perjanjian itu berupa perjanjian timbal balik, maka berdasarkan pasal 1266 sekarang kreditur berhak untuk menuntut pembatalan perjanjian, dengan atau tanpa disertai dengan tuntutan ganti rugi.

23 Boedi Harsonoi, Beberapa Analisa Tentang Hukum Agraria, Bagian I, Esa Study Club, Jakarta, h. 108.
Pembuktian Keabsahan Jual beli Di Bawah Tangan dikaitkan dengan Putusan No. 130/Pdt.G/2012/PN.Mlg

$$
\begin{aligned}
& \text { Sahnya jual beli } \\
& \text { ditentukan oleh terpenuhinya } \\
& \text { syarat-syarat materiil bagi } \\
& \text { jual beli: }
\end{aligned}
$$

1) Syarat-syarat umum bagi sahnya suatu perbuatan hukum (Pasal 1320 KUH Perdata);

2) Pembeli memenuhi syarat bagi pemegang hak atas tanahnya;

3) Tidak dilanggar ketentuan Landreform;

4) Dilakukan secara tunai, terang, dan nyata. (KptsMA 123/K/1970)

Persoalan menyangkut kepada siapa pada salah satu pihak dibebani pembuktian tersebut adalah masalah "beban pembuktian" (bewijslast). Didalam proses acara perdata, Hakim terikat kepada perundang-undangan, sebagaimana yang ditentukan dalam Pasal 163 HIR/283 $\mathrm{RBg}$ yang menentukan setiap orang yang menyatakan mempunyai suatu hak atau peristiwa guna meneguhkan 
haknya atau untuk menyangkal/membantah hak orang lain, maka ia diwajibkan membuktikan adanya hak tersebut atau adanya peristiwa tersebut.

Perjanjian jual beli di bawah tangan dilakukan dengan itikad tidak baik, maka hal ini mengakibatkan suatu perikatan menjadi tidak memiliki kekuatan hukum mengikat, dalam arti seketika batal demi hukum dan dianggap tidak pernah ada perikatan tersebut karena tidak lagi memenuhi unsurunsur Pasal 1320 KUH Perdata yaitu tidak ada kehendak yang bebas. Sebagaimana telah dijelaskan dalam ketentuan Pasal 1338 KUHPerdata yaitu:"Semua persetujuan yang dibuat secara sah sesuai dengan undang-undang berlaku sebagai undang-undang bagi mereka yang membuatnya. Persetujuan itu tidak dapat ditarik kembali selain dengan kesepakatan kedua belah pihak, atau karena alasan- alasan yang ditentukan oleh undang-undang. Persetujuan harus dilaksanakan dengan itikad baik."

Dipandang dari segi pihak yang berperkara, alat bukti adalah alat atau upaya yang digunakan untuk meyakinkan hakim di muka sidang pengadilan. ${ }^{24}$ Menurut sistem HIR dan RBg. Hakim terikat dengan alat-alat bukti yang sah, yang diatur oleh undang-undang. Ini berarti hakim hanya boleh mengambil putusan berdasarkan alat-alat bukti yang telah diatur oleh undang-undang.

Menurut ketentuan Pasal 164 HIR-284 RBg, ada lima macam alat bukti dalam perkara perdata yaitu : alat bukti surat, alat bukti saksi, persangkaan, pengakuan dan sumpah. ${ }^{25}$

1. Bukti Surat

\footnotetext{
Anshoruddin, Hukum Pembuktian Menurut Hukum Acara Islam dan Hukum Positif, Pustaka Pelajar, Surabaya, 2004, h.25

25 Ropaun Rambe, Hukum Acara Perdata Lengkap, Sinargrafika, Jakarta, 2013, cet-7, h. 233
} 
Putusan

No.

130/Pdt.G/2012/PN.Mlg

menjelaskan bahwa bahwa

penggugat

dalam

membuktikan

gugatanya

dengan melengkapi berkas

yaitu Kwitansi tanda

penerimaan uang pelunasan

pembebasan tanah tertanggal

14 Maret 2011, fotocopuy

surat pengikat jual beli No :

04/dan .SPJB/I/2011 tanggal

11 Januari 2011. Keabsahan

bukti yang diajukan

dibuktikan dengan pengakuan

tanda tangan para pihak

dalam suat perjanjian. Hal

tersebut diatas sejalan dapat

dijelaskan dengan apabila

para pihak mengakui surat

bukti yang diajukan

dipengadilan maka surat

dibawah tangan tersebut

setara dengan akta otentik

yang dikeluarkan

PPAT/Notaris.

Agar akta di bawah tangan dapat dijadikan alat bukti maka harus memenuhi syarat formil dan materiil. Menurut M. yahya Harahap, SHsyarat formil dan materiil akta di bawah tangan sebagai berikut:

1) Syarat formil akta di bawah tangan:

a). Bersifat partai

b). Pembuatannya tidak di hadapan pejabat.

c). Harus bermaterai

d). Ditanda tangani kedua belah pihak

2) Syarat materiil akta di bawah tangan:

a) Isi akta di bawah tangan berkaitan langsung dengan apa yang diperkarakan

b) Isi akta di bawah tangan itu tidak bertentangan dengan hukum, kesusilaan, agama dan ketertiban umum

c) Sengaja diperbuat untuk alat bukti.

Kekuatan pembuktian akta di bawah tangan adalah sama dengan akta otentik. Jika isi dan tanda tangan diakui oleh pihak lawan. Hanya dapat disingkirkan jika isinya bertentangan dengan hukum, ada unsur paksaan dalam pembuatan atau ada penipuan. Jika isi dan tandatangan yang ada dalam 
akta di bawah tangan itu disangkal oleh pihak lawan, maka akta di bawah tangan itu mempunyai nilai kekuatan yang sama dengan bukti permulaan. Akibat dari penyangkalan ini secara berdiri sendiri tidak cukup membuktikan dalil gugat, harus disempurnakan dengan alat bukti yang lain seperti saksi atau sumpah tambahan. ${ }^{26}$

Pada umumnya akta di bawah tangan tidak mempunyai kekuatan bukti lahir, karena tanda tangan dapat dimungkiri. Sedangkan kekuatan bukti formil dan materiil sama dengan akta otentik.

2. Bukti dengan saksi-saksi;

Menurut ketentuan Pasal 1895 BW dinyatakan "Pembuktian dengan saksi diperkenankan dalam segala hal kecuali oleh peraturan perundang ditentukan lain.

3. Persangkaan;
Persangkaan-persangkaan

bukanlah alat bukti yang mandiri. Persangkaanpersangkaan dapat menjadi alat bukti dengan merujuk pada alat bukti lainnya dengan demikian juga satu persangkaan saja bukanlah merupakan alat bukti. Pada praktik peradilan, ada dua macam persangkaan yaitu sebagai berikut: ${ }^{27}$

4. Pengakuan

Pasal 174-176 HIR/ 311-313 RBg. Dibedakan: Pengakuan di muka sidang dan Pengakuan di luar sidang.

5. Sumpah

$$
\begin{aligned}
& \text { Sumpah pada } \\
& \text { umumnya adalah suatu } \\
& \text { pernyataan yang khidmat, } \\
& \text { diberikan atau diucapkan } \\
& \text { pada waktu memberikan janji } \\
& \text { atau keterangan dengan } \\
& \text { mengingat sifat maha kuasa } \\
& \text { dari Tuhan, dan percaya } \\
& \text { bahwa siapa yang memberi } \\
& \text { keterangan atau janji atau } \\
& \text { keterangan yang tidak benar } \\
& \text { akan dihukum oleh Tuhan. }
\end{aligned}
$$

${ }^{27}$ Salim H.S, Perancangan kontrak \& Memorandum Of Understanding (MOU), Sinar Grafika, Jakarta, 2011, h. 26 
Akta di bawah tangan merupakan akta yang dibuat oleh para pihak tanpa perantara seorang pejabat umum. ${ }^{28}$ Tulisan di bawah tangan membutuhkan pengakuan kebenaran atas tulisan tersebut dari para pihak dan saksi-saksi lain. Namun jika tanda tangan dalam tulisan di bawah tangan itu sudah diakui oleh para pihak, maka tulisan tersebut berkekuatan mengikat dan sempurna sebagai alat bukti. Perjanjian tertulis otentik juga disebut akta otentik. Pengertian akta otentik secara teoritis adalah surat atau akta yang sejak semula dengan sengaja secara resmi dibuat untuk pembuktian apabila suatu hari terjadi suatu sengketa, ${ }^{29}$

Kedudukan Hukum akta dibawah tangan dalam jual beli hak atas tanah dikaitkan dengan Putusan No. 130/Pdt.G/2012/PN.Mlg

${ }^{28}$ Salim H.S, Perancangan kontrak \& Memorandum Of Understanding (MOU). h. 29

${ }^{29}$ Asri Diamitri Lestari, "Kekuatan Alat Bukti Akta Otentik yang di Buat Oleh Notaris Dalam Pembuktian Perkara Perdata di Pengadilan Negeri Sleman, 2014, h. 5
Surat jual beli tanah yang dilakukan di bawah tangan dapat dijadikan salah satu alat bukti. Sesuai dengan maksud dalam Pasal 3 Peraturan Menteri Pertanian dan Agraria Nomor 2 Tahun 1962, yaitu : Permohonan untuk penegasan tersebut dalam Pasal 1 mengenai hakhak yang tidak diuraikan di dalam sesuatu hak tanah sebagai yang dimaksudkan dalam Pasal 2, diajukan kepada Kepala Kantor Pendaftaran Tanah yang bersangkutan dengan disertai $^{30}$ :

1. Tanda bukti haknya, yaitu bukti surat pajak hasil bumi/verponding Indonesia atau bukti surat pemberian hak oleh instansi yang berwenang.

2. Surat keterangan Kepala Desa, dikuatkan oleh Asisten Wedana, yang :

a) Membenarkan surat atau surat-surat bukti hak itu

${ }^{30}$ Peraturan Menteri Pertanian Dan Agraria Nomor 2 Tahun 1962 Tentang Penegasan Konversi Dan Pendaftaran Bekas Hak-Hak Indonesia Atas Tanah 
b) Menerangkan apakah tanahnya tanah perumahan atau tanah pertanian.

c) Menerangkan siapa yang mempunyai hak itu, kalau ada turunan surat-surat jual beli tanahnya

3. Tanda bukti kewarganegaraan yang sah dari yang mempunyai hak, sebagai yang dimaksud dalam Pasal 2 sub.

Adapun jual beli yang dilakukan secara di bawah tangan sebagaimana yang dimaksud oleh Peraturan Pemerintah Nomor 24 Tahun 1997, adalah perbuatan hukum yang dilakukan oleh penjual dan pembeli dengan maksud untuk memindahkan hak atas tanah dengan cara membuat surat perjanjian dengan materai secukupnya dan telah diketahui oleh Kepala Adat atau Kepala Desa atau Lurah. Sedangkan obyek dari jual beli itu sendiri adalah tanah bekas hak milik adat, yaitu tanah-tanah yang dulu dimilliki oleh masyarakat pribumi sebelum berlakunya Undang-Undang

Nomor 5 Tahun 1960, sehingga diatur menurut Hukum Adat ${ }^{31}$.

Peralihan hak atas tanah di bawah tangan ini dilakukan dengan suatu perjanjian yang dibuat diatas kwitansi yang dibubuhi materai atau kertas segel yang didalamnya dituangkan perjanjian yang mengikat kedua belah pihak yang harus ditandatangai oleh para pihak dan saksi-saksi. Peralihan hak atas tanah secara jual beli itu walaupun dilakukan dengan di bawah tangan, namun dikuatkan dengan para saksi yang dapat dinyatakan sah menurut Hukum Adat.

Kedudukan hukum akta bawah tangan dalam putusan yang dibahas penulis terletak pada pembuktian perjanjian berdasarkan SPJB NO. 001/ dan. SPJ / I / 2011 ttg. 11 januari 2011. SPJ yang diterbitkan para pihak dibuat secara bawah tangan dengan

${ }^{31}$ Peraturan Pemerintah Republik Indonesia Nomor 24 tahun 1997 tentang pendaftaran tanah 


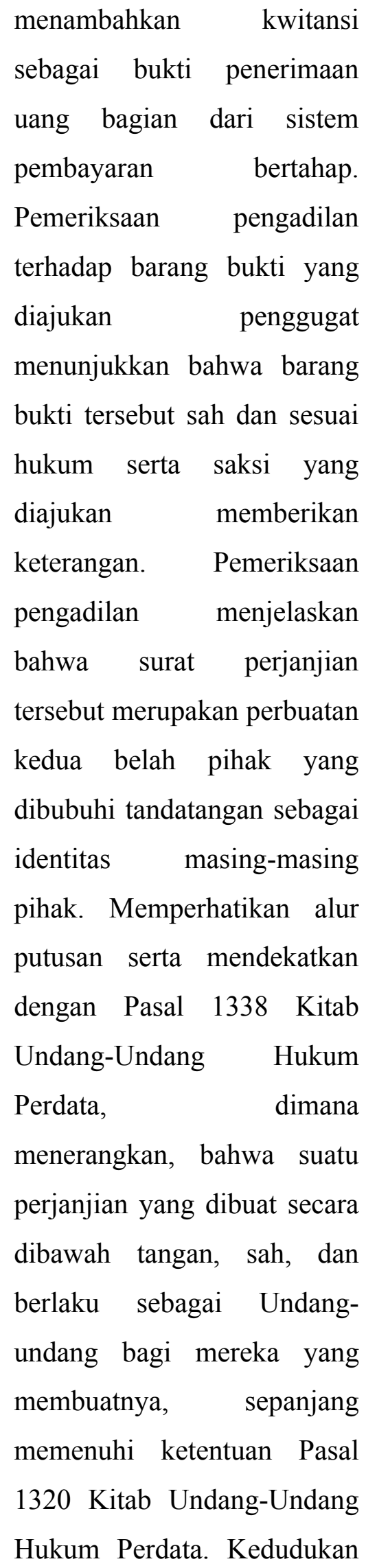

perjanjian bawahtangan yang dilakukan para pihak pada dasarnya benar akan tetapi hal yang bertentangan yaitu itikad buruk dari penjual yang bukan menyerahkan SHGB sesuai perjanjian justru mengangunkanya pada BANK.

Perlindungan Hukum Bagi Pembeli Dalam Jual Beli Hak Atas Tanah Yang Bersertifikat Yang Dilakukan Di Bawah Tangan Dikaitkan Dengan Putusan No. 130/Pdt.G/2012/Pn.Mlg

Keabsahan Jual Beli Tanah dengan Akta di Bawah Tangan

Keabsahan jual beli tanah jika ditinjau dari Undang-Undang ataupun Peraturan Pemerintah, jual beli tanah yang dianggap sah yaitu jual beli tanah dilakukan di hadapan pejabat pembuat akta tanah atau jual beli dengan akta otentik yang disahkan oleh pejabat yang berwenang. Hal tersebut 
sesuai dengan PP No.24

tahun 1997 Tentang

Pendaftaran Tanah dalam

Pasal 37 angka 1

menyebutkan bahwa

peralihan hak atas tanah dan

hak milik atas satuan rumah

susun melalui jual beli, tukar

menukar, hibah pemasukan

dalam perusahann dan

perbuatan hukum

pemindahan hak lainnya.

Kecuali pemindahan hak melalui lelang hanya dapat didaftarkan jika dibuktikan dengan akta yang dibuat oleh PPAT yang berwenang menurut ketentuan peraturan perundang-undangan yang berlaku. $^{32}$

Menurut pasal 1320

KUHPerdata, suatu perjanjian harus memenuhi persyaratan sebagai berikut:

a. Sepakat mereka yang mengikatkan dirinya;

b. Cakap untuk membuat suatu perjanjian;

c. Mengenai suatu hal tertentu;

d. Suatu sebab yang halal.

${ }^{32}$ K.Wantjik Saleh, Hak Anda Atas Tanah, Ghalia Indonesia, Jakarta,1977, h. 30 .
Dua syarat yang pertama, dinamakan syaratsyarat subyektif, karena mengenai orang-orangnya atau subyeknya yang mengadakan perjanjian, sedangkan dua syarat yang terakhir dinamakan syarat syarat obyektif karena mengenai perjanjiannya sendiri atau obyek dari perbuatan hukum yang dilakukan itu. Berikut ini akan dijelaskan satu persatu mengenai syarat- syarat tersebut:

a. Sepakat mereka yang mengikatkan dirinya

Kesepakatan antara para pihak yang membuat perjanjian berarti terjadinya pertemuan atau kesesuaian kehendak yang terjadi diantara para pihak. ${ }^{33}$ Kedua subyek yang mengadakan perjanjian itu harus bersepakat atau setuju mengenai hal -hal yang pokok dari perjanjian yang diadakan itu.

33 Akhmad Budi Cahyono dan Surini Ahlan Sjarif, Mengenal Hukum Perdata, CV. Gitama Jaya, Jakarta, 2008, h. 129. 
b. Kecakapan untuk membuat suatu perikatan

$$
\text { Pasal }
$$

KUHPerdata telah menentukan siapa saja para pihak yang tidak cakap, yaitu $^{34}$ :

1) Orang-orang yang belum dewasa;

2) Mereka yang ditaruh di bawah pengampuan;

3) Orang-orang perempuan, dalam hal-hal yang ditetapkan oleh undangundang, dan pada umumnya semua orang kepada siapa undangundang telah melarang membuat perjanjianperjanjian tertentu.

\section{c. Suatu hal tertentu}

$$
\begin{aligned}
& \text { Syarat yang ketiga } \\
& \text { adalah hal tertentu. Hal } \\
& \text { tertentu maksudnya adalah } \\
& \text { obyek perjanjian atau prestasi } \\
& \text { yang diperjanjikan harus } \\
& \text { jelas, dapat dihitung, dan } \\
& \text { dapat ditentukan jenisnya. } \\
& \text { Dalam perjanjian jual beli } \\
& \text { misalnya hal tertentu adalah }
\end{aligned}
$$

\footnotetext{
Pasal 1330 KUHPerdata Tentang Kecakapan dalam Pembuatan persetujuan/ Perikatan
}

harga dan barang, jadi dalam perjanjian jual beli tidak dimungkinkan untuk membuat perjanjian tanpa ditentukan harganya dan jenis barang yang dijual, meskipun barang yang dijual tidak harus telah ada pada saat perjanjian disepakati. Dengan demikian dimungkinkan barang yang diperjanjikan baru ada dikemudian hari sesuai dengan yang diperjanjikan. ${ }^{35}$

\section{d. Suatu sebab yang halal}

Syarat terakhir tentang syarat sahnya perjanjian adalah sebab yang halal. Dengan sebab ini yang dimaksud adalah isi perjanjian. Sebab yang halal maksudnya adalah isi suatu perjanjian tidak boleh bertentangan dengan undangundang, ketertiban umum dan kesusilaan. Pengertian tidak boleh bertentangan dengan undang-undang di sini adalah undang-undang yang bersifat melindungi kepentingan

35 Akhmad Budi Cahyono dan Surini Ahlan Sjarif, Mengenal Hukum Perdata, Jakarta:CV. Gitama Jaya, 2008, halaman. 132. 
umum, sehingga jika

dilanggar

dapat

membahayakan kepentingan

umum. ${ }^{36}$

Akibat Praktik Jual Beli Tanah di Bawah Tangan

Menurut Gunawan

Widjaja dan Kartini Muljadi, ketentuan umum mengenai perikatan untuk menyerahkan sesuatu (Pasal1235 KUH Perdata), dan ketentuan yang diatur secara khusus dalam ketentuan jual-beli (Pasal 1474), penjual memiliki 3 (tiga) kewajiban pokok mulai dari sejak jual-beli terjadi menurut ketentuan Pasal 1458 KUH Perdata. Menurut ketentuan tersebut, secara prinsip penjual memiliki kewajiban untuk ${ }^{37}$ :

a. Memelihara dan merawat kebendaan yang akan diserahkan kepada pembeli hingga saat penyerahannya.

\footnotetext{
Hardijan Rusli, Hukum Perjanjian Indonesia dan Common Law,cet. 2, Pustaka Sinar Harapan, Jakarta, 1996, h. 99.

${ }^{37}$ Marilang, Hukum Perikatan,
} Perikatan yang lahir dari perjanjian, h.192 b. Menyerahkan kebendaan yang dijual pada saat yang telah ditentukan, atau jika tidak telah ditentukan saatnya, atas permintaan pembeli.

c. Menanggung kebendaan yang dijual tersebut.

Mengenai penyerahan atau levering dalam KUH Perdata, menganut 'sistem causal' yaitu suatu sistem yang menggantungkan sahnya levering itu pada dua syarat $^{38}$ :

a. Penyerahan atau levering telah dilaksanakan oleh yang berhak berbuat bebas (beschikkingsbevoegd) terhadap orang yang dilevering.

b. Sahnya titel dalam perjanjian jual beli yang menjadi dasar levering (penyerahan).

Pasal1504 KUH Perdata, yang menyatakan bahwa: Si penjual diwajibkan menanggung terhadap cacatcacat tersembunyi pada

${ }^{38}$ R. Soeroso, Perjanjian Di bawah Tangan Pedoman Praktis Pembuatan dan Aplikasi Hukum, Sinar Grafika, Jakarta, 2011), h 13 
barang yang dijual, yang membuat barang itu tidak sanggup untuk pemakaian yang dimaksudkan, atau yang demikian mengurangi pemakaian itu sehingga, seandainya si pembeli mengetahui cacat-cacat itu, ia sama sekali tidak akan membeli barangnya, atau tidak akan membelinya selain dengan harga yang kurang.

Maksud dari Pasal
tersebut bahwa cacat yang
membuat barang tersebut
tidak dapat dipakai untuk
keperluan yang dimaksud dan
cacat tersebut tidak diketahui
oleh pembeli secara normal
atau wajar pada saat
ditutupnya perjanjian, dalam hal ini perjanjian jual beli. Mengapa dikatakan sebagai cacat tersembunyi, karena cacat tersebut tidak mudah kelihatan apabila tidak dilihat secara jeli dan teliti, Tetapi apabila cacat yang dimaksud sudah terlihat sebelumnya, maka barang tersebut tentu bukan lagi disebut sebagai cacat tersembunyi, melainkan dikategorikan sebagai cacat yang nampak atau kelihatan.

\section{Perlindungan Hukum Bagi pembeli dalam Jual Beli Hak Atas Tanah yang bersertifikat yang dilakukan dengan Akta di Bawah Tangan dikaitan Putusan No. 130/ Pdt.G/2012/PN.MIg}

\begin{tabular}{lrr}
\multicolumn{2}{c}{ Pemberian } & putusan \\
sesuai & Pasal & 1491 \\
KUHPerdata & memberikan \\
perlindungan & berupa \\
penanggungan & yang \\
menyebutkan & bahwa:
\end{tabular}
"Penanggungan yang menjadi kewajiban penjual terhadap pembeli, adalah untuk menjamin dua hal, yaitu : pertama, penguasaan barang yang dijual itu secara aman dan tenteram; kedua, terhadap adanya cacat-cacat barang tersebut yang tersembunyi, atau yang sedemikian rupa hingga menerbitkan alasan untuk pembatalan pembeliannya."

Penanggungan tersebut walaupun tidak diperjanjikan di awal pembuatan perjanjian jual beli namun tetap berlaku mengikat penjual 


\begin{tabular}{|c|c|}
\hline sebagaimana & persetujuan \\
\hline dalam Pasal 1492, yaitu: & mana pihak yang \\
\hline "Meskipun pada waktu & mengikatkan dirinya untuk \\
\hline penjualan dilakukan tiada & menyerahkan suatu barang, \\
\hline dibuat janji tentang & dan pihak yang lain untuk \\
\hline penanggungan, & membayar \\
\hline penjual adalah demi hukum & dijanjikan", dan pasal 1458 \\
\hline diwajibkan menanggung & BW menyebutkan "Jual beli \\
\hline pembeli terhadap suatu & dianggap telah terjadi antara \\
\hline penghukuman. & kedua belah pihak, segera \\
\hline Untuk mengatakan & setelah orang-orang \\
\hline bahwa seseorang melakukan & kesepakatan \\
\hline wanprestasi dalam suatu & tentang \\
\hline perjanjian, kadang-kadang & beserta harganya, mes \\
\hline tidak mudah karena sering & barang itu belum diserahk \\
\hline sekali juga tidak dijanjikan & dan harganya belum diba \\
\hline dengan tepat kapan suatu & Setelah kedua $b$ \\
\hline pihak diwajibkan melakukan & pihak mengakui adanya \\
\hline prestasi yang diperjanjikan. & perjanjian jual beli \\
\hline Dalam hal bentuk prestasi & dasarnya perjanjian ba \\
\hline debitur dalam perjanjian yang & tangan tersebut sudah sa \\
\hline berupa tidak berbuat sesuatu, & dengan akta otentik, \\
\hline akan mudah ditentukan sejak & sebab itu hakim dalam \\
\hline kapan debitur melakukan & memberikan keadilan dengan \\
\hline wanprestasi yaitu sejak pada & menggunakan pasal 1457 \\
\hline saat debitur berbuat sesuatu & sebagaimana bunyinya diat \\
\hline yang tidak diperbolehkan & Itikad buruk penjual harus \\
\hline dalam perjanjian. & menjalankan apa yang telah \\
\hline pengadilan & tertera sebelumnya pada surat \\
\hline dalam putusan menimbang & perjanjian oleh sebab \\
\hline bahwa pasal $1457 \mathrm{BW}$ & hakim memberikan pu \\
\hline menyatakan: ". & enyatakan \\
\hline
\end{tabular}


perjanjian yang diperbuat kedua belah pihak serta kwitansi sebagai tanda bukti pembayaran awal yang dilakukan oleh pembeli.

\section{E. KESIMPULAN}

1. Proses peralihan hak atas tanah melalui jual beli menurut Peraturan Pemerintah Nomor 24 Tahun 1997 meliputi: pertama, persiapan pembuatan akta jual beli hak atas tanah, terlebih dahulu PPAT wajib melakukan pemeriksaan pada kantor pertanahan kabupaten/kota mengenai keabsahan sertifikat hak atas tanah yang bersangkutan. Kedua, pelaksanaan pembuatan akta PPAT harus dihadiri oleh pihak yang melakukan perbuatan hukum yang bersangkutan (penjual dan pembeli) atau orang yang dikuasakan olehnya dengan surat kuasa tertulis sesuai dengan peraturan Perundangundangan yang berlaku. Ketiga, pendaftaran peralihan hak, PPAT wajib menyampaikan akta PPAT dan dokumen-dokumen lain yang diperlukan untuk keperluan pendaftaran peralihan hak atas tanah yang bersangkutan kepada kantor pertanahan kabupaten/kota selambat-lambatnya tujuh hari kerja. Keempat, penyerahan sertifikat.

2. Kedudukan para pihak dalam jual beli pada Putusan No. 130.Pdt.G/2012/PN. Mlg tidak ada yang salah hal ini karenakan perjanjian bawah tangan tidak menjadi larangan dalam jual beli hal ini dipertegas oleh Yurisprudensi Mahkamah Agung Nomor 126.K/Sip/ 1976 tanggal 4 April 1978 yang memutuskan bahwa :"Untuk sahnya jual beli tanah, tidak mutlak harus dengan akta yang dibuat oleh dan dihadapan Pejabat Pembuat Akta Tanah. Akta Pejabat ini hanyalah suatu alat bukti".

3. Perlindungan hukum berdasarkan putusan terhadap pembeli yang mana penjual wanprestasi yaitu disahkanya perjanjian bawah tangan, mewajibkan penjual menyerahkan SHGB No. 984 Luas $150 \mathrm{~m}^{2}$ ATAS NAMA pt. 
Dewata Abdi Nusa dengan GS

No. 00243/2007 tanggal 04

Oktober 2007, mewajibkan

penjual mengajukan akta jual

beli (AJB) tanah SHGB No. 984
Luas $150 \mathrm{~m}^{2}$ ATAS NAMA pt. Dewata Abdi Nusa dengan GS No. $00243 / 2007$ tanggal 04

Oktober 2007.

\section{DAFTAR PUSTAKA}

\section{a. Buku}

Abdulkadir Muhammad, 1982, Hukum Perikatan, Alumni, Bandung.

Dominikus Rato, 2010, Filsafat Hukum Mencari: Memahami dan Memahami Hukum, Laksbang Pressindo, Yogyakarta.

E.Zaenal Arifin, Dasar-dasar Penulisan Karangan Ilmiah, Gramedia Widiasarana Indonesia, Jakarta, 1998

Edi Warman, 2015, Monograf Metodologi Penelitian Hukum, Medan, PT Sofmedia.

Effendi Perangin, 1991, Hukum Agraria Indonesia Suatu Telaah Dari Sudut Pandang Praktisi Hukum, Jakarta : Rajawali Pres.

H.S, Salim, 2004. Perkembangan Hukum Kontak Innominaat Di Indonesia. Jakarta, Penerbit Sinar Grafika

Hernoko, Agus Yudha, 2010, Hukum Perjanjian Asas Proporsionalitas dalam Kontrak Komersial, Kencana Prenada Media Grup, Jakarta

John Salindeho, 1987. Masalah Tanah Dalam Pembangunan, Sinar Grafika, Jakarta.

Juswito Satrio, 2002, Hukum Perikatan, Perikatan yang Lahir dari Perjanjian, Bandung:, Citra Aditya Bakti

Kamello Tan, 2014 Hukum Jaminan (suatu kebutuhan yang didambakan). Alumni. Bandung

Lubis Yamin dan Rahim Lubis, 2008. Hukum Pendaftaran Tanah, Mandar Maju, Bandung.

Manan, Abdul, 2001. Penerapan Hukum Acara Perdata di Lingkungan Peradilan Agama. Jakarta, Al Hikmah

Purba Hasim. 2007. Pengantar ilmu hukum indonesia diktat - USU. Universitas Sumatera Utara, Fakultas Hukum. 2007.

Pusbakum, 2001, Sutedi, Adrian. Peralihan Hak Atas Tanah Dan Pendaftarannya.Jakarta. Sinar Grafika

R.Subekti, Hukum Perjanjian, Jakarta:Intermasa, 2011), (untuk selanjutnya disebut Buku I). 
Rambe, Ropaun, 2013. Hukum Acara Perdata Lengkap. Jakarta: Sinargrafika, cet-7

Riduan Syahrani, 1999, Rangkuman Intisari Ilmu Hukum, Penerbit Citra Aditya Bakti,Bandung.

Salim HS, 2003, Hukum Kontrak, Penerbit Sinar Grafika, Jakarta.

Satrio, J, 1995. Hukum Perikatan, Perikatan yang Lahir dari Perjanjian. Bandung: PT. Citra Aditya Bakti

Warman Edi, 2015, Monograf Metodologi Penelitian Hukum, PT Sofmedia, Medan, h. 25

Widjaja, Gunawan dan Kartini Muljadi, 2004, Jual beli, Jakarta, PT Raja Grafindo Persada

Widjaja, Gunawan, 2007. Seri Hukum Bisnis: Memahami Prinsip Keterbukaan (Aanvullend Recht) dalam Hukum Perdata. Jakarta, PT Raja Grafindo Persada

\section{b. Jurnal}

Adriano Felix Cristian. 2015. Analisis Yuridis Atas Turunnya Kekuatan Pembuktian Akta Notaris Menurut Undang-Undang Nomor 2 Tahun 2014 Tentang Jabatan Notaris, Magister Kenotariatan USU.

Dwi Hastuti Pranciska Romana, Keabsahan Jual Beli Hak atas Tanah di Bawah tangan di Desa Patihan Kecamatan Sidoharjo Kabupaten Sragen (Tinjauan Beberapa Kasus Terkait di Pengadilan Negeri di Surakarta), Jurnal Reportorium, ISSN:2355-2646, Volume II No. 2

Nasution Iswarni, 2018. Analisis Yuridis Terhadap Akta Pelepasan Hak Dengan Ganti Rugi Yang Dibuat Akibat Wanprestasi Hutang Piutang (Studi Putusan Perkara Perdata Nomor : 48/Pdt.G/2011/Pn.Mdn Tanggal 3 Oktober 2011). Magister Kenotariatan USU. Medan.

Paulus, 2015.Analisis Yuridis Terhadap Munculnya Sertipikat Hak Milik Atas Tanah Perkebunan Kelapa Sawit Perorangan Atas Kekuatan Surat Keterangan Kepala Desa Yang Ganda (Studi Putusan PTUN Nomor : 08/G/ 2011/PTUN-MDN. Magister Kenotariatan USU. Medan.

Rodeka Siregar Agusman. 2017. Problematika Pendaftaran Tanah Adat Menjadi Hak Milik Tanpa Persetujuan Seluruh Ahli Waris pada Kantor Pertanahan Kabupaten Samosir. Magister Kenotariatan USU, Medan.

\section{c. Internet}

www. Proferty.com (Diakses 12 Juni 2018)

https://ismayadwiagustina.wordpress.com/2019/06/26/pengertian-teori/

Dwika, "Keadilan dari Dimensi Sistem Hukum", http://hukum.kompasiana.com. (02/04/2011), diakses pada 24 Juli 2018 
